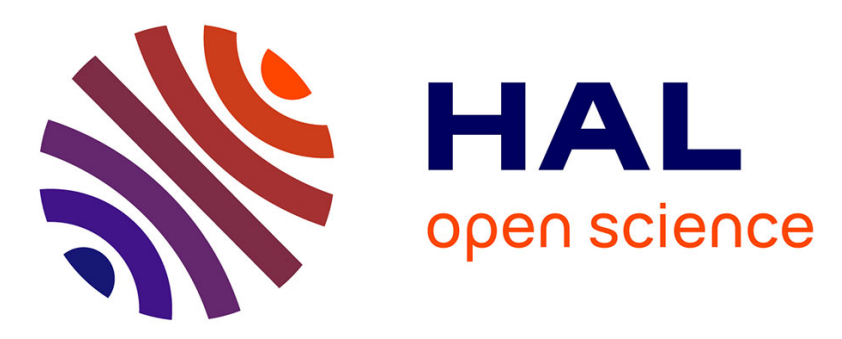

\title{
Environmentally relevant mixture of S-metolachlor and its two metabolites affects thyroid metabolism in zebrafish embryos
}

Eliška Rozmánková, Marek Pípal, Lucie Bláhová, Naveen Chandran Njattuvetty, Bénédicte Morin, Patrice Gonzalez, Luděk Bláha

\section{To cite this version:}

Eliška Rozmánková, Marek Pípal, Lucie Bláhová, Naveen Chandran Njattuvetty, Bénédicte Morin, et al.. Environmentally relevant mixture of S-metolachlor and its two metabolites affects thyroid metabolism in zebrafish embryos. Aquatic Toxicology, 2020, 221, pp.105444. 10.1016/j.aquatox.2020.105444 . hal-03434081

\section{HAL Id: hal-03434081 https://hal.science/hal-03434081}

Submitted on 25 Nov 2021

HAL is a multi-disciplinary open access archive for the deposit and dissemination of scientific research documents, whether they are published or not. The documents may come from teaching and research institutions in France or abroad, or from public or private research centers.
L'archive ouverte pluridisciplinaire HAL, est destinée au dépôt et à la diffusion de documents scientifiques de niveau recherche, publiés ou non, émanant des établissements d'enseignement et de recherche français ou étrangers, des laboratoires publics ou privés. 


\section{Environmentally relevant mixture of S-metolachlor and its two metabolites affects thyroid metabolism in zebrafish embryos}

\section{AUTHORS}

Rozmankova Eliska $^{1,2}$, Pipal Marek ${ }^{1}$, Blahova Lucie ${ }^{1}$, Njattuvetty Chandran Naveen ${ }^{1}$, Morin 6 Benedicte $^{2}$, Gonzalez Patrice ${ }^{2}$, Blaha Ludek ${ }^{1}$

1 Masaryk University, Faculty of Science, RECETOX, Kamenice 753/5, 62500 Brno, Czech

9 Republic

2 University of Bordeaux, EPOC, UMR 5805, 33400 Talence, France

11

HIGHLIGHTS (3-5, max 85 characters per highlight)

- Herbicide toxicity analysis on embryo-larval stages of zebrafish

- Reduced spontaneous movements in embryos exposed to S-metolachlor alone and in mixture

- S-metolachlor caused no effect on molecular level, unlike its metabolites

- Low concentration of pesticide mixture overexpressed thyroid genes dio2, thra, thrb

- Larvae locomotion, heart rate not affected; minor developmental malformations found

\section{KEYWORDS (6 max)}

- Zebrafish embryo, embryotoxicity, pesticide mixture, environmental concentration, sublethal effect, metabolite

\section{Abstract $<400$ words}

Herbicides and their metabolites are found in water bodies where they may harm non-target organisms. Their effects at environmentally relevant concentrations are often unclear, especially concerning mixture of pesticides. This study thus investigated the impacts of one of the most used herbicides: S-metolachlor and its two metabolites, metolachlor oxanilic acid (MOA) and metolachlor ethanesulfonic acid (MESA) on the development of zebrafish embryos (Danio rerio). Embryos were exposed to the pure substances and their environmentally relevant mixture until $120 \mathrm{hpf}$ (hours post-fertilization). The focus was set on sublethal endpoints such as malformations, hatching success, length of fish, spontaneous movements, heart rate and locomotion of zebrafish larvae. Moreover, gene expression levels of eight genes linked to the thyroid system disruption, oxidative stress defense, mitochondrial metabolism, regulation of the cell cycle and retinoic acid signaling pathway were analyzed. 
35 Exposure to the S-metolachlor $(1 \mu \mathrm{g} / \mathrm{L})$ and to the pesticide mixture $(1 \mu \mathrm{g} / \mathrm{L}$ of each 36 substance) significantly reduced spontaneous tail movements of $21 \mathrm{hpf}$ embryos. Few rare developmental malformations were observed, but only in larvae exposed to more than $100 \mu \mathrm{g} / \mathrm{L}$ of pure substances (craniofacial deformation, non-inflated gas bladder, yolk sac malabsorption) and to $30 \mu \mathrm{g} / \mathrm{L}$ of each substance in the pesticide mixture (spine deformation). However, no effect on hatching success, length of larvae, heart rate or larvae locomotion were found. Strong responses were detected at the molecular level, especially on the p53 gene regulating the cell cycle, caused by the pesticide mixture $(1 \mu \mathrm{g} / \mathrm{L}$ of each substance), MESA $43(30 \mu \mathrm{g} / \mathrm{L})$ and MOA $(100 \mu \mathrm{g} / \mathrm{L})$, as well as on the cyp26al - gene encoding for cytochrome P450 after exposure to the pesticide mixture ( $1 \mu \mathrm{g} / \mathrm{L}$ of each substance). Genes implicated in the thyroid system disruption (dio2, thra, thrb) were all overexpressed following exposure to the environmentally relevant concentrations of the pesticide mixture $(1 \mu \mathrm{g} / \mathrm{L}$ of each substance) and to the metabolite MESA $(1 \mu \mathrm{g} / \mathrm{L})$. In conclusion, the zebrafish thyroid system disruption was revealed not only by the overexpressed genes, but also by some of the developmental malformations considered as markers of this type of disruption (mainly gas bladder and yolk sac abnormalities) and spontaneous tail movements linked to the T4 hormone influencing its neurodevelopment. Thus, the thyroid system disruption represents a

52 likely hypothesis behind the effects caused by the low environmental concentrations of 53 S-metolachlor, its two metabolites and their mixture. 
S-metolachlor is one of the most commonly used pesticides in the world (Atwood and Paisley-Jones, 2017). This selective pre-emergent herbicide from the chloroacetanilides family was first registered in 1997 (Heydens et al., 2010). It is an S-enantiomer of 2-chloro$\mathrm{N}$-(2-ethyl-6-methylphenyl)-N-(1-methoxypropan-2-yl)acetamide. It replaced the racemic metolachlor mixture due to its higher herbicidal activity (Müller et al., 2001; Thomas Poiger, 2002), thus reducing the quantity of pesticide needed by $40 \%$ (Blaser and Spindler, 1997). S-metolachlor inhibits the biosynthesis of very-long-chain fatty acids (Götz and Böger, 2004) and interferes with gibberellin synthesis enzymes (Rose et al., 2016), thereby inhibiting the growth of target plants such as grass weeds in corn fields (Heydens et al., 2010). However, S-metolachlor can easily contaminate surface water by agricultural runoff (Zemolin et al., 2014) and it is thus often detected in surface or coastal waters (Accinelli et al., 2002; De Liguoro et al., 2014; Fauvelle et al., 2018; Glinski et al., 2018; Kapsi et al., 2019; Meffe and de Bustamante, 2014; Ryberg et al., 2014). In soil, S-metolachlor is microbially degraded to two principal metabolites (Zemolin et al., 2014): metolachlor oxanilic acid (MOA) and metolachlor ethanesulfonic acid (MESA), which are mobile and persistent in the environment (Sidoli et al., 2016). As a result, these degradation products are often detected in higher concentrations than the parent compound itself in water samples (Elliott and VanderMeulen, 2017; Hladik et al., 2005). However, there is a general lack of information about the toxicity of individual pesticide metabolites and their mixtures occurring in the environment. Only recently, some studies highlighted the importance of aquatic toxicity of environmentally relevant pesticide mixtures (Gustavsson et al., 2017; Tian et al., 2018). Furthermore, the importance of evaluating mixture toxicity is emphasized by the European Chemicals Agency (2014).

The contamination of aquatic environments by herbicides may adversely affect non-target organisms such as fish. Fish are among the most sensitive organisms in aquatic ecosystems and are used as standard testing species in the hazard assessment of chemicals and their mixtures (Hayes et al., 2019). To the best of our knowledge, studies on the effects of $\mathrm{S}$-metolachlor or its metabolites on fish are scarce. Most use high concentrations (mg/L) to obtain $\mathrm{LC}_{50}$ or $\mathrm{EC}_{50}$ values, and these are far from being environmentally relevant (Dobšíková et al., 2011; Munn et al., 2006; Quintaneiro et al., 2017). Unlike these studies, Jin et al. (2011) observed that lower concentrations $(\mu \mathrm{g} / \mathrm{L})$ of metolachlor (mixture of both $\mathrm{R}$ - and $\mathrm{S}$ enantiomers) altered the thyroid system in Japanese medaka. Thyroid system disruption was 
also caused by low concentrations of acetochlor $(\mu \mathrm{g} / \mathrm{L})$, another member of the chloroacetanilide family (Yang et al., 2015). In other non-target aquatic organisms, S-metolachlor and its metabolites MOA and MESA induced developmental abnormalities in Pacific oyster larvae and sperm at low environmental concentrations (Mai et al., 2014). Moreover, the deleterious effects of environmental concentrations of S-metolachlor and MOA on crayfish were also reported (Velisek et al., 2018a, 2018b). Although several studies pointed out the toxicity of high concentrations of these substances on non-target aquatic organisms (Gutiérrez et al., 2019; Munn et al., 2006; Quintaneiro et al., 2018, 2017), comprehensive information on sublethal effects caused by environmental concentrations is still missing.

Early life stage zebrafish (Danio rerio) are widely used as sensitive and reliable alternative toxicity models with multiple advantages including high-throughput screening, embryo transparency, quick breeding and development, a sequenced genome (Love et al., 2004) and are in compliance with the 3Rs principle (Russell et al., 1959). Zebrafish development is highly influenced by its thyroid metabolism (Jarque and Piña, 2014). Moreover, the early development of the zebrafish thyroid system is comparable to its development in humans (Alt et al., 2006), complete with a similar hypothalamus-pituitary-thyroid (HPT) axis (Porazzi et al., 2009). This similarity makes the zebrafish a suitable model for evaluating thyroid gland disruption (Raldúa et al., 2012). In a recent review, Spaan et al. (2018) write that the complexity of thyroid disruption assessment calls for the evaluation of multiple endpoints. Morphological effects, transcription level of several genes interfering with the HPT axis, hatching, heart rate, behavior and swim bladder inflation were cited as the most common.

Although the toxicity of high concentrations of S-metolachlor on non-target aquatic organisms has been previously studied, the effects posed by low environmentally relevant concentrations of this compound and its metabolites have yet to be examined. The present study investigated the sublethal toxicity of environmentally relevant concentrations of S-metolachlor, its two metabolites MOA and MESA and their mixture on embryo-larval stages of Danio rerio. We evaluated apical endpoints of zebrafish embryos, conducted a neurobehavioral study measuring swimming activity to assess potential neurotoxicity and assessed biochemical responses by measuring the transcription changes of selected genes. This integrative approach allowed for detailed examination of sublethal toxicity, including potential thyroid metabolism disruption. 


\section{Materials and methods}

\subsection{Chemicals}

122 S-metolachlor (S-M, CAS 87392-12-9, Pestanal, purity $\geq 98.0 \%$ ), metolachlor oxanilic acid 123 (MOA, CAS 152019-73-3, Pestanal, purity $\geq 98.0 \%$ ), metolachlor ethanesulfonic acid 124 (MESA, CAS 947601-85-6, Pestanal, purity $\geq 95.0 \%$ ) were purchased from Sigma-Aldrich. 125 Their stock solutions $(50 \mathrm{mg} / \mathrm{L})$ were prepared in Milli-Q water and were stored at $4{ }^{\circ} \mathrm{C}$. The 126 hormone triiodothyronine (T3, dissolved in methanol, CAS 6893-02-3, purity $\geq 95 \%$, 127 purchased from Sigma-Aldrich, used immediately) was used as positive control in the gene 128 modulation experiments. Ethanol absolute (CAS 64-17-5, purity $\geq 99.8 \%$, purchased from 129 VWR Chemicals) was used as positive control in the spontaneous movement analysis and for

130 the PCR analysis. ISO medium (ISO, 1996) $\left(\mathrm{CaCl}_{2} * 2 \mathrm{H}_{2} \mathrm{O}(294 \mathrm{mg} / \mathrm{L})\right.$, $131 \mathrm{MgSO}_{4} * 7 \mathrm{H}_{2} \mathrm{O}(123.3 \mathrm{mg} / \mathrm{L}), \mathrm{NaHCO}_{3}(63 \mathrm{mg} / \mathrm{L}), \mathrm{KCl}(5.5 \mathrm{mg} / \mathrm{L})$ in Milli-Q water) was used 132 to prepare the final dilutions for the tests. RNAlater ${ }^{\circledR}$ (Ambion) was purchased from Sigma133 Aldrich.

\section{$134 \quad 2.2$ Test organism}

135 Zebrafish (Danio rerio) embryos were collected from an unspecified wild type zebrafish 136 strain maintained at RECETOX, Masaryk University (Czech Republic). Adult fish are held in 137 aquariums with tap water at $26 \pm 1{ }^{\circ} \mathrm{C}$, at 14 : 10h light:dark photoperiod and fed 3 times a day 138 with commercially available feeds (of which at least once with live brine shrimp Artemia 139 salina). About 10-14 hours before the experimentation a box for collecting the embryos is 140 placed in the aquarium and the spawning is induced in the morning by turning the light on. 141 The eggs are collected 30 minutes after, rinsed and transferred to the ISO medium. Only 142 fertilized and normally developing eggs are picked for the tests using a stereomicroscope 143 (OLYMPUS, Japan) and exposed at 3-4 hpf (hours post fertilization). The embryos were then 144 maintained at $26^{\circ} \mathrm{C}$, at 14:10h light:dark photoperiod till $120 \mathrm{hpf}$ without feeding or renewal 145 of test solutions.

\section{$146 \quad 2.3$ FET (Fish embryo toxicity) test}

147 The experiments were conducted in accordance with the fish early-life stage toxicity guideline 148 (OECD, 2013). Selected eggs were exposed to the chosen herbicide S-metolachlor and its two 149 metabolites MOA and MESA. The experiments were done with individual compounds and 150 then with the mixture of the three. Chosen concentrations are based on environmental 
151 concentrations detected in the rivers in the Czech Republic and in the Arcachon Bay in France 152 during 2010-2014 (Table 1).

153 
155 Maximum concentrations of metolachlor and its metabolites MOA and MESA detected in 156 Czech rivers (CHMU (Czech Hydrometeorological Institute), 2018) and Arcachon Bay in 157 France (source) during 2010-2014. Number of samples: N=703 values for every substance in 158 Arcachon Bay; N=13 175, 7503 and 7502 for metolachlor, MOA and MESA respectively in 159 surface water)

\begin{tabular}{ccccc} 
& Metolachlor & MOA & MESA & Location \\
\cline { 1 - 3 } $\begin{array}{c}\text { Maximum } \\
\begin{array}{c}\text { concentration } \\
(\text { ng/L) }\end{array}\end{array}$ & 5800 & 4200 & 4200 & Surface water (CZ) \\
\cline { 1 - 3 }$\%$ of values & 1696 & 1609 & 1059 & Arcachon Bay (FR) \\
$>100 \mathrm{ng} / \mathrm{L}$ & $3.5 \%$ & $4.1 \%$ & $19.1 \%$ & Surface water (CZ) \\
\hline
\end{tabular}

160

The lowest used test concentration $(1 \mu \mathrm{g} / \mathrm{L})$ reflects the actual environmental concentration, and three higher (non-lethal) concentrations were also tested (30, 100 and $300 \mu \mathrm{g} / \mathrm{L}$ ).

163 Corresponding concentrations in $\mathrm{nmol} / \mathrm{L}$ are showed in Supplementary Table S2. The mixture exposure included two concentration levels: $1 \mu \mathrm{g} / \mathrm{L}$ of each substance and $30 \mu \mathrm{g} / \mathrm{L}$ of each substance. ISO medium was used as negative control. The tests were conducted in glass crystallization dishes with transparent lids containing $20 \mathrm{ml}$ of media and 20 embryos in three replicates. Every test was repeated independently three times with eggs from different spawning. Mortality, hatching success and malformations were controlled daily using a stereomicroscope. Eventual dead embryos/larvae were immediately removed from dishes to prevent contamination. Length of larvae (without the caudal fin) was measured on the last, fifth, day of the experiment on photos of larvae mounted in mixture of cellulose and anesthetics MS-222. Fifteen fish per replicate in 3 independent tests were measured. Photos were analyzed using the software QuickPhoto Micro 2.3.

174 "Morphological score" endpoint was assessed in order to evaluate global state of individual

175 fish using slightly modified approach as previously published (Panzica-Kelly et al., 2010).

176 Every fish embryo is classified using 0-3 point scores (description is in Supplementary Figure 177 S1).

\subsection{Light: dark locomotor test}

179 Embryos for the locomotor activity analysis were handled as described above (2.3). The 180 evening before measurements (to allow for acclimation), larvae were transferred to 181 transparent 96-well microplates (Gama, Czech Republic), one larva per well. The distribution 182 was random, 32 fish per exposure condition were used. Only morphologically normal, i.e. 
183

184

185

186

187

188

189

190

191

192

193

194

195

196

197

198

199

200

201

202

203

204

205

206

207

208

209

210

211

212

213

non-malformed embryos were used. The experimentations were performed during the $5 \mathrm{dpf}$ between 9 am and $16 \mathrm{pm}$. Prior to the experiment, the microplates were kept for 1 hour next to the ZEBRABOX (Viewpoint Life Sciences) at $26^{\circ} \mathrm{C}$ for acclimation after the transport. Measurement done in the ZEBRABOX consisted of four 15 minutes alternating cycles (white light, i.e. $100 \%$ stimulus / dark, i.e. no stimulus / white light / dark). Total distances swam $(\mathrm{mm})$ by individual fish were measured with integration period of 60 seconds and processed in real time using the software Zebralab (Viewpoint Life Sciences). The threshold between "inactive" fish and "active" fish was set on $0.3 \mathrm{~cm} / \mathrm{sec}$. The sensitivity threshold of ZEBRABOX was set on 120 .

\subsection{Spontaneous movement and heartbeat}

Embryos were handled as described above (2.2) and exposed to concentrations of 1 and $100 \mu \mathrm{g} / \mathrm{L}$ of substances alone and to the mixtures at two concentration levels (1 and $30 \mu \mathrm{g} / \mathrm{L}$ of each substance in the mixture). They were maintained at $26{ }^{\circ} \mathrm{C}$ until $21 \mathrm{hpf}$ when randomized capture of videos was realized till $23 \mathrm{hpf}$. Crystallization dish containing 20 embryos (= one replicate) was acclimatized under the stereomicroscope for $30 \mathrm{sec}$ and then 2 min video was captured. Positive control (1\% v/v ethanol) was used to enhance the spontaneous movements (tail coils). Videos were then analyzed by DanioScope software (Noldus, Netherlands) and reported as spontaneous movements per minute.

The same embryos were used for the heart rate activity measurement during the $3 \mathrm{dpf}$ starting at 72 hpf. Hatched larvae were first put in solution of $2.5 \%$ methylcellulose containing 50 $\mathrm{mg} / \mathrm{L}$ of anesthetics MS-222 and placed in Petri dish. Larvae were acclimatized for 10 seconds under the stereomicroscope and 20 second videos were captured. Videos were analyzed using the DanioScope software and reported as beat per minute.

\subsection{Zebrafish exposures for analysis of gene expressions}

Embryos were handled as described above (2.3) and exposed to 1, 30 and $100 \mu \mathrm{g} / \mathrm{L}$ of pesticides assessed alone and two concentrations of the mixture of the three pesticides ( 1 and $30 \mu \mathrm{g} / \mathrm{L}$, respectively of each compound). Hormone T3 (triiodothyronine) was used as positive control to assess the expression of thyroid-related genes. Dead or heavily malformed embryos/larvae were removed daily. Whole larvae were collected at $120 \mathrm{hpf}$ into pools of 20 larvae per Eppendorf tube containing $500 \mu \mathrm{RNA}$ Rater ${ }^{\circledR}$ and stored at $-20{ }^{\circ} \mathrm{C}$ upon RNA extraction. 


\subsubsection{RNA isolation}

215 The total RNAs were extracted using the SV Total RNA Isolation System Kit (Promega). 216 Whole larvae were homogenized in $500 \mu$ l of RNA Lysis Buffer using glass beads (Sigma) in 217 the FastPrep®-24 (M.P. Biomedicals, USA). Lysed samples were collected, centrifuged and 218 mixed with $450 \mu \mathrm{l}$ of $75 \% \mathrm{v} / \mathrm{v}$ ethanol and transferred on the spin column. Handling with spin 219 columns was performed according to the manufacturer's instructions. Before the DNase 220 incubation step, an additional centrifuge step was added (13500 rpm, 2 minutes) to dry the 221 column. All RNA samples were treated with DNase I mixture (40 $\mu 1$ of Yellow core buffer, $2225 \mu \mathrm{l}$ of $\mathrm{MnCl}_{2}$ and $5 \mu \mathrm{l}$ of DNase I) for 15 minutes in water bath at $37^{\circ} \mathrm{C}$. The rest of the isolation was performed according to the manufacturer's instructions and purified RNAs were collected in $50 \mu \mathrm{l}$ of Nuclease-Free water. The concentration and purity of collected RNA samples were verified spectrophotometrically at 260/280 and 260/230 nm wavelength with Nanodrop ${ }^{\mathrm{TM}}$. Purity of all the samples was between $2.0-2.1$ for the ratio $260 / 280$ and $1.8-2.2$

227 for the ratio $260 / 230$.

\subsubsection{Reverse transcription}

Reverse transcription phase was performed with GoScript ${ }^{\mathrm{TM}}$ Reverse Transcription System kit (Promega) according to the manufacturer's instructions using TProfessional Thermocycler (Biometra, Analytik Jena). Purified RNA $(1 \mu \mathrm{g})$ was reversely transcribed in order to get final volume of $20 \mu \mathrm{l}$ of cDNA, and it was stocked at $-20{ }^{\circ} \mathrm{C}$ upon qPCR analysis.

\subsubsection{Quantitative PCR}

2348 genes were selected to evaluate the effects of chosen pesticides and their mixture on the thyroid hormone system, mitochondrial metabolism, regulation of the cell cycle and oxidative stress defense. Three reference zebrafish genes were used in the analysis ( $\beta$-actin, efla and rpl13). Functioning and references of used primers are shown in Table 2. Sequences, efficiencies, and accession numbers are presented in Supplementary Table S1. Primers were purchased from Elisabeth Pharmacon (Czech Republic).

240 QPCR was carried out with Brillant III Ultra-fast SYBR Green QPCR Master Mix kit 241 (Stratagene-Agilent) on the LightCycler® 480 (Roche). Each qPCR mix (20 $\mu$ l) contained $2425 \mu \mathrm{l}$ of cDNA (10 times diluted), $2 \mu 1$ of reverse and forward primer $(2 \mu \mathrm{M})$ and $10 \mu 1$ of 243 SYBR from the kit and $3 \mu 1$ of nuclease free water.

244 LightCycler was set according to the instructions of the SYBR kit manufacturer (Stratagene245 Agilent). Briefly, the pre-incubation lasted 3 min at $95{ }^{\circ} \mathrm{C}$, then the amplification consisted of 
24645 cycles with 1 cycle at $95{ }^{\circ} \mathrm{C}$ for $5 \mathrm{sec}$ and $60{ }^{\circ} \mathrm{C}$ for $10 \mathrm{sec}$. The melting curve continued at $24795^{\circ} \mathrm{C}$ for $5 \mathrm{sec}$ and at $65^{\circ} \mathrm{C}$ for $1 \mathrm{~min}$. Finally, the cooling step was performed at $40{ }^{\circ} \mathrm{C}$ for $24830 \mathrm{sec}$. Melting curves of every reaction were analyzed to assess reaction specificity. The data 249 were normalized to the mean of the $\mathrm{Ct}$ values for three reference genes, $\beta$-act, elfla and $r p l 13$ 250 and analyzed using the $2^{-\Delta \Delta C T}$ method (Livak and Schmittgen, 2001). Results are shown as 251 fold changes of exposed to control group.

\section{Table 2}

253 Primers used for qPCR analysis in zebrafish (Danio rerio) and their references.

\begin{tabular}{|l|l|l|}
\hline Gene & Function & References \\
\hline$\beta$-act & Reference gene & Dedeh et al., 2015 \\
\hline efla & Reference gene & Gentès et al., 2015 \\
\hline$r p l 13$ & Reference gene & Gentès et al., 2015 \\
\hline $12 S$ & Mitochondrial metabolism & Arini et al., 2015 \\
\hline$p 53$ & Regulation of the cell cycle/apoptose & Gentès et al., 2015 \\
\hline cat & Oxidative stress defense & Lerebours et al., 2009 \\
\hline sod1 & Oxidative stress defense & Gentès et al., 2015 \\
\hline cyp26al & RA (retinoic acid) signaling pathway & Oliveira et al., 2013 \\
\hline dio2 & Thyroid hormone system & Yan et al., 2012 \\
\hline thra & Thyroid hormone system & Yan et al., 2012 \\
\hline thrb & Thyroid hormone system & Yan et al., 2012 \\
\hline
\end{tabular}

\subsection{Chemical analysis and water quality}

256 At the beginning and at end of the experiments, $\mathrm{pH}$, dissolved oxygen and conductivity were 257 controlled. Saturation by oxygen was always higher than 98\%. pH varied between 7.6-7.9. 258 Conductivity varied between 500 and $700 \mu \mathrm{S} / \mathrm{cm}$ with no difference between ISO medium and pesticide solutions. Stability of substances during the five-day experiment was verified by measuring their concentrations by LC-MS/MS analysis as described in detail in

261 Supplementary Material S1. In brief, LC-MS/MS was performed with a Waters LC 262 chromatograph (Waters, Manchester, U.K.) using Acquity BEH C18 column and gradient 263 elution. Detection was performed on a Xevo TQ-S quadrupole mass spectrometer (Waters 264 Manchester, U.K.) after ESI ionisation in a positive ion mode The analytes were quantified 265 using external calibration of metolachlor, MOA and MESA $(0.1-500 \mu \mathrm{g} / \mathrm{L}$ in $20 \%$ of 266 methanol) and the limit of detection (LOD, signal to noise ratio $\mathrm{S} / \mathrm{N}>3$ ) and quantification 267 (LOQ, S/N>10) were 0.05 and $0.1 \mu \mathrm{g} / \mathrm{L}$, respectively for each analyte.

\section{$268 \quad 2.8$ Data analysis}

269 Length of larvae was assessed with one-way ANOVA test. Sum of different observed malformations in all replicates of the three independent experiments were compared with 
271 control animals using Fisher's exact test in software GraphPad Prism (Version 5, GraphPad 272 Software).

273 Different independent locomotion tests (independent experiments) were all assessed 274 statistically apart because of high variability in control fish. Final results are presented as 275 mean of fold changes with control of the three independent experiments.

276 Data of locomotion tests, spontaneous movements and heart rate were verified for normality 277 (Shapiro-Wilk test; $p>0.01$ ) and homoscedasticity (Levene test; $p>0.05$ ), and if confirmed, 278 ANOVA followed by Dunnet post-hoc test was used. In the other case, non-parametric 279 Kruskall-Wallis test with Mann-Withney post-hoc test was used.

280 All data for the gene expression analysis were treated as described above (Shapiro-Wilk test; $281 \mathrm{p}>0.01$; Levene test; $\mathrm{p}>0.05)$. Eventual values higher or smaller than 3 standard deviations 282 were discarded. Data were log normalized prior to the analysis. ANOVA followed by Dunnet 283 post-hoc test was used. If normality or homoscedasticity were not confirmed, non-parametric 284 Kruskall-Wallis test with Mann-Whitney post-hoc tests were performed. All analyses were 285 performed using software Statistica 13.3 (StatSoft, version 13.2, USA). 


\section{Results}

\subsection{Exposure and chemical analysis}

Stability of all three compounds during the five-day experiment was verified. Nominal and measured concentrations, as well as the stability are shown in Supplementary Table S2. The

292 concentrations of compounds were stable with the maximum decline of $13,3 \%$ at $30 \mu \mathrm{g} / \mathrm{L}$ of

293 S-metolachlor. Measured values corresponded to nominal ones in case of MOA and were slightly higher at S-metolachlor and MESA. To simplify the presentation, nominal concentrations are shown and discussed in the results and discussions sections.

\subsection{Mortality, hatching success, length of fish and malformation results}

No significant effects on mortality were observed in any concentration tested of S-metolachlor, MOA, MESA or mixture of the three compounds. All controls had mortality $<10 \%$ as preconized by OECD guideline (OECD, 2013). Survival in all tested conditions was between $97.2 \%$ and $100 \%$. Similarly, no significant effects on hatching success were found in all conditions tested. Hatching success values were between $95 \%$ and

$302100 \%$ in all variants.

303 Observed developmental abnormalities and length of fish are presented in Table 3. Generally, no patterns or dose-response effects were observed after exposure to S-metolachlor, its two metabolites MOA and MESA or in the mixture. No effects on the length of fish were observed in any condition tested. The most frequently observed malformations were at swim bladder (non-inflation) and yolk sac (malabsorption). No statistically significant effects were detected after exposures to the lower concentrations (1 and $30 \mu \mathrm{g} / \mathrm{L})$ of S-metolachlor, MOA and MESA or after exposure to the low concentration mixture $(1 \mu \mathrm{g} / \mathrm{L}$ of each substance).

310 Following statistically significant effects were observed: S-metolachlor induced non-inflation 311 of the swim bladder $(100 \mu \mathrm{g} / \mathrm{L})$ and malabsorption of the yolk sac $(300 \mu \mathrm{g} / \mathrm{L})$ and MESA $312(300 \mu \mathrm{g} / \mathrm{L})$ induced craniofacial malformations. In addition, mixture of the three substances at 313 concentration of $30 \mu \mathrm{g} / \mathrm{L}$ per each substance induced spinal deformations. Morphological 314 score endpoint which allows assessment of each fish individually revealed as most 315 problematic concentrations of 100 and $300 \mu \mathrm{g} / \mathrm{L}$ of $\mathrm{S}$-metolachlor, $100 \mu \mathrm{g} / \mathrm{L}$ of MESA and $31630 \mu \mathrm{g} / \mathrm{L}$ of mixture. 
Table 3 Frequencies (\%) of different types of developmental malformations, length of larvae $(\mu \mathrm{m})$ and morphological score of zebrafish after 120 hours exposure to different concentrations of pesticide, metabolites and their mixtures. Each value represents mean \pm standard deviation from 3 independent experiments each based on $\mathrm{N}=60$ embryos. $* \mathrm{P}<0.05 ; * * \mathrm{P}<0.01$

\begin{tabular}{|c|c|c|c|c|c|c|c|c|c|c|c|}
\hline & & $\mu \mathrm{m}$ & \multicolumn{8}{|c|}{$\%$} & \multirow{3}{*}{ 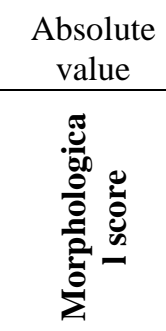 } \\
\hline & \multirow{2}{*}{ 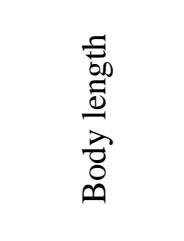 } & \multirow{2}{*}{$\underset{\overparen{\Xi}}{\tilde{\Xi}}$} & \multirow{2}{*}{ 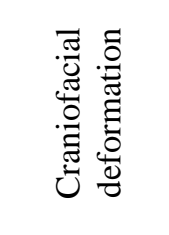 } & \multirow{2}{*}{ 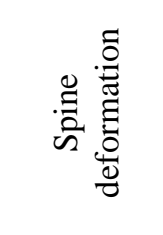 } & \multirow{2}{*}{ 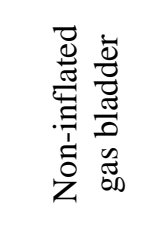 } & \multirow{2}{*}{ 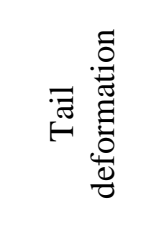 } & \multirow{2}{*}{ 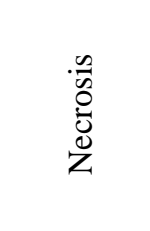 } & \multirow{2}{*}{ 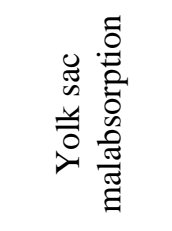 } & \multirow{2}{*}{ 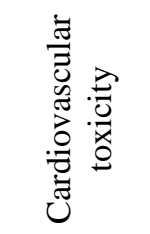 } & \\
\hline Con & $\begin{array}{l}\text { tration } \\
\mathrm{L}\end{array}$ & & & & & & & & & & \\
\hline \multirow{5}{*}{ 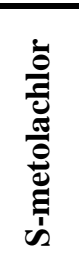 } & Control & $3768 \pm 103$ & $1.1 \pm 1.6$ & $1.1 \pm 1.6$ & $0 \pm 0$ & $0.6 \pm 0.8$ & $0 \pm 0$ & $0.6 \pm 0.8$ & $1.1 \pm 0.8$ & $1.1 \pm 1.6$ & $0.9 \pm 1.0$ \\
\hline & 1 & $3772 \pm 118$ & $0.6 \pm 0.8$ & $1.7 \pm 1.4$ & $1.1 \pm 0.8$ & $2.8 \pm 2.8$ & $0 \pm 0$ & $0.6 \pm 0.8$ & $3.9 \pm 2.8$ & $0 \pm 0$ & $1.6 \pm 1.1$ \\
\hline & 30 & $3767 \pm 131$ & $1.7 \pm 2.4$ & $2.8 \pm 3.9$ & $1.1 \pm 1.6$ & $3.3 \pm 1.4$ & $0 \pm 0$ & $0 \pm 0$ & $3.3 \pm 3.6$ & $0 \pm 0$ & $1.8 \pm 1.8$ \\
\hline & 100 & $3763 \pm 123$ & $1.7 \pm 1.4$ & $2.3 \pm 3.2$ & $0.6 \pm 0.8$ & $4.6 \pm 1.6^{*}$ & $0 \pm 0$ & $0.6 \pm 0.8$ & $4.0 \pm 0.8$ & $0 \pm 0$ & $2.0 \pm 1.1^{*}$ \\
\hline & 300 & $3738 \pm 131$ & $1.7 \pm 1.4$ & $2.8 \pm 1.6$ & $1.7 \pm 1.4$ & $2.3 \pm 0.8$ & $0 \pm 0$ & $0.6 \pm 0.8$ & $5.8 \pm 2.2 *$ & $0 \pm 0$ & $2.2 \pm 0.8^{*}$ \\
\hline \multirow{5}{*}{$\stackrel{\overleftarrow{s}}{\Sigma}$} & Control & $3714 \pm 136$ & $1.1 \pm 0.8$ & $2.3 \pm 2.1$ & $0.6 \pm 0.8$ & $3.4 \pm 2.4$ & $0 \pm 0$ & $2.8 \pm 4.0$ & $2.3 \pm 2.1$ & $0 \pm 0$ & $1.9 \pm 1.5$ \\
\hline & 1 & $3712 \pm 130$ & $2.3 \pm 2.2$ & $2.3 \pm 2.2$ & $1.8 \pm 1.5$ & $1.8 \pm 2.5$ & $0 \pm 0$ & $0.6 \pm 0.8$ & $1.8 \pm 2.5$ & $1.2 \pm 1.7$ & $1.8 \pm 1.9$ \\
\hline & 30 & $3719 \pm 160$ & $1.1 \pm 1.6$ & $0.6 \pm 0.8$ & $0 \pm 0$ & $2.9 \pm 1.6$ & $0 \pm 0$ & $0.6 \pm 0.8$ & $1.7 \pm 0$ & $1.7 \pm 2.4$ & $1.3 \pm 0.8$ \\
\hline & 100 & $3678 \pm 169$ & $3.5 \pm 2.4$ & $2.3 \pm 1.6$ & $2.9 \pm 0.7$ & $5.1 \pm 2.4$ & $0 \pm 0$ & $1.7 \pm 2.4$ & $2.8 \pm 0.8$ & $3.4 \pm 4.8$ & $3.0 \pm 1.4$ \\
\hline & 300 & $3694 \pm 163$ & $1.1 \pm 1.6$ & $1.1 \pm 1.6$ & $1.7 \pm 1.4$ & $3.9 \pm 0.7$ & $0 \pm 0$ & $2.3 \pm 3.2$ & $2.9 \pm 0.8$ & $0.6 \pm 0.8$ & $2.1 \pm 1.6$ \\
\hline \multirow{5}{*}{ 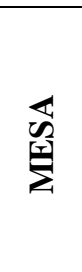 } & Control & $3661 \pm 140$ & $0.6 \pm 0.8$ & $0.6 \pm 0.8$ & $1.1 \pm 0.8$ & $2.2 \pm 2.1$ & $0 \pm 0$ & $0 \pm 0$ & $1.7 \pm 1.4$ & $0 \pm 0$ & $0.7 \pm 0.5$ \\
\hline & 1 & $3708 \pm 112$ & $0 \pm 0$ & $1.1 \pm 1.6$ & $0 \pm 0$ & $2.2 \pm 2.1$ & $0 \pm 0$ & $0 \pm 0$ & $0.6 \pm 0.8$ & $0 \pm 0$ & $0.6 \pm 0.2$ \\
\hline & 30 & $3700 \pm 146$ & $0 \pm 0$ & $1.1 \pm 1.6$ & $0 \pm 0$ & $1.1 \pm 1.6$ & $0 \pm 0$ & $0.6 \pm 0.8$ & $0.6 \pm 0.8$ & $0 \pm 0$ & $0.6 \pm 0.4$ \\
\hline & 100 & $3683 \pm 118$ & $1.1 \pm 0.8$ & $4.4 \pm 5.2 *$ & $1.7 \pm 1.4$ & $3.3 \pm 1.4$ & $0 \pm 0$ & $1.1 \pm 1.6$ & $2.8 \pm 0.8$ & $0 \pm 0$ & $2.0 \pm 1.7 * *$ \\
\hline & 300 & $3628 \pm 127$ & $0 \pm 0$ & $2.3 \pm 2.1$ & $0.6 \pm 0.8$ & $1.1 \pm 0.8$ & $0 \pm 0$ & $0 \pm 0$ & $1.7 \pm 0$ & $0 \pm 0$ & $0.9 \pm 0.4$ \\
\hline \multirow{3}{*}{$\underset{z}{2}$} & Control & $3755 \pm 149$ & $0.7 \pm 1.0$ & $4.3 \pm 2.6$ & $0.6 \pm 0.8$ & $6.3 \pm 4.4$ & $0.6 \pm 0.8$ & $2.3 \pm 1.7$ & $6.9 \pm 6.6$ & $0.6 \pm 0.8$ & $3.2 \pm 1.7$ \\
\hline & 1 (of each) & $3763 \pm 163$ & $2.8 \pm 0.8$ & $2.9 \pm 1.6$ & $3.4 \pm 2.8$ & $4.5 \pm 0.8$ & $0.6 \pm 0.8$ & $1.1 \pm 0.8$ & $5.1 \pm 2.4$ & $0 \pm 0$ & $3.1 \pm 1.1$ \\
\hline & 30 (of each) & $3740 \pm 193$ & $3.1 \pm 2.5$ & $8.0 \pm 1.0$ & $4.6 \pm 3.5^{*}$ & $6.7 \pm 5.2$ & $0 \pm 0$ & $3.0 \pm 2.3$ & $12.2 \pm 8.6$ & $1.9 \pm 1.6$ & $5.9 \pm 2.0 * *$ \\
\hline
\end{tabular}




\subsection{Light:dark locomotion test and heartbeat}

322 None of the studied compounds or their mixtures caused any statistically significant effects on

323 the swimming behavior. Detailed results are shown in Supplementary Material S2. Similarly,

324 there were no effects observed at the heart rate of zebrafish larvae, detailed results are shown

325 in Supplementary Material S3.

\subsection{Spontaneous movements}

328 Results of the spontaneous movements of the zebrafish embryos are presented in Figure 1. 329 Environmental concentrations of S-metolachlor $(1 \mu \mathrm{g} / \mathrm{L})$ and of the mixture of the three substances $(1 \mu \mathrm{g} / \mathrm{L}$ of each substance) significantly $(\mathrm{P}=0.001$ and 0.022 respectively) reduced

331 frequency of the tail movements. $0.5 \%$ solution of ethanol, used as positive control, 332 significantly enhanced tail movements $(\mathrm{P}=0.009)$.

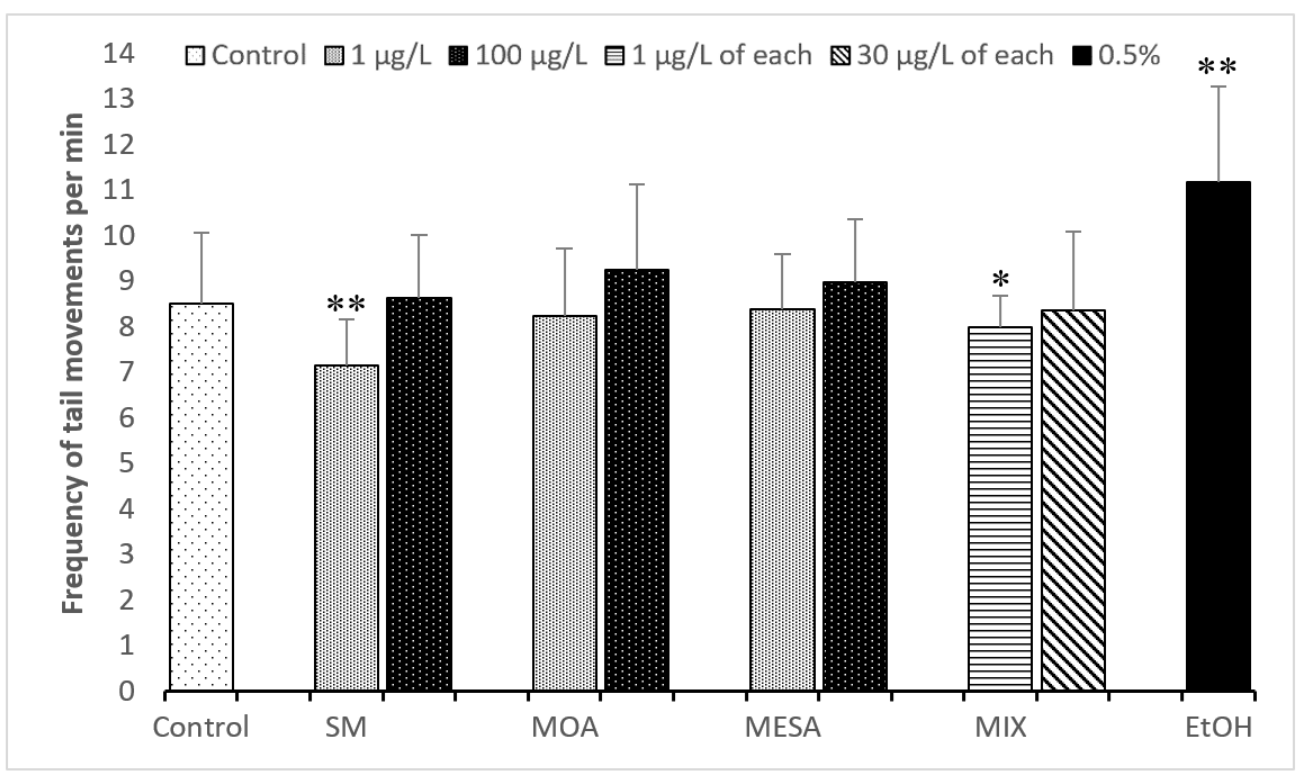

334 Figure 1. Spontaneous tail movements frequency per minute in zebrafish embryos exposed 335 SM: S-metolachlor; MOA: Metolachlor oxanilic acid; MESA: Metolachlor ethanesulfonic 336 acid; MIX: mixture of SM, MOA and MESA (concentration of 1 et $30 \mu \mathrm{g} / \mathrm{L}$ of each substance in the mixture); EtOH: ethanol; $* \mathrm{P}<0.05, * * \mathrm{P}<0.01$ 


\subsection{Analysis of gene expression}

340 Gene expression of eight pre-selected genes was analyzed. Results are shown in Figure 2 as

341 fold changes of ratio between selected genes and housekeeping genes. Exposures to T3 was

342 used as positive control for thyroid-related genes.

343 The expression of mitochondrially encoded 12S rRNA (12S) gene was not significantly 344 upregulated or downregulated in comparison with the control for all the concentrations of all 345 the pesticides tested (Fig.3a). P53, gene related to the regulation of the cell cycle and cell 346 apoptosis, was significantly upregulated at $100 \mu \mathrm{g} / \mathrm{L}$ of MOA (1.8-fold, $\mathrm{P}=0.005)$ and $30 \mu \mathrm{g} / \mathrm{L}$ 347 of MESA (2-fold, $\mathrm{P}=0.022$ ). The mixture of SM, MOA and MESA in concentration of $1 \mu \mathrm{g} / \mathrm{L}$ 348 of each pesticide (2-fold, $\mathrm{P}<0.001$ ) induced significant upregulation of p53 (Fig.3b). 349 Oxidative stress defense associated genes catalase - cat (Fig.3c) and copper/zinc superoxide 350 dismutase - sodl (Fig.3d) were not affected by any of the pesticides tested.

351 We also studied the genes associated to RA signaling pathway: gene coding for cytochrome 352 P450, family 26, subfamily A, polypeptide 1 - cyp26al (Fig.3e) and genes associated to 353 thyroid metabolism disruption: iodothyronine deiodinase 2 - dio2 (Fig.3f), thyroid hormone 354 nuclear receptor $\alpha \mathrm{a}$ - thra (Fig.3g), and thyroid hormone nuclear receptor beta - thrb (Fig.3h). 355 None of the four genes was deregulated after exposure to S-metolachlor. On the contrary, the 356 metabolites and the mixture affected gene transcriptions. MOA significantly increased the 357 expression of dio2 (3.5-fold, $\mathrm{P}=0.015)$ and thrb (1.8-fold, $\mathrm{P}=0.034)$ in the highest 358 concentration tested $100 \mu \mathrm{g} / \mathrm{L}$. MESA significantly increased the mRNA expression level of 359 dio2 (5.6-fold, $\mathrm{P}=0.002)$, thra (2.1-fold, $\mathrm{P}=0.004)$ and thrb (1.9-fold, $\mathrm{P}=0.003)$ in the 360 concentration of $1 \mu \mathrm{g} / \mathrm{L}$. Upregulation of thra was also observed in the MESA concentration 361 of $30 \mu \mathrm{g} / \mathrm{L}$ (2-fold, $\mathrm{P}=0.027$ ). The mixture of the three substances (at low level - $1 \mu \mathrm{g} / \mathrm{L}$ of 362 each substance) significantly upregulated the gene expression in all four genes - cyp26al 363 (2.3-fold, $\mathrm{P}<0.001$ ), dio2 (2.5-fold, $\mathrm{P}=0.007)$, thra (2.5-fold, $\mathrm{P}=0.001)$, thrb (2.2-fold, $364 \mathrm{P}=0.001)$. The T3 hormone significantly increased the expression of the mRNA transcription 365 level of cyp26al (4.2-fold, $\mathrm{P}=0.001)$ and thra (4.7-fold, $\mathrm{P}<0.001)$. 


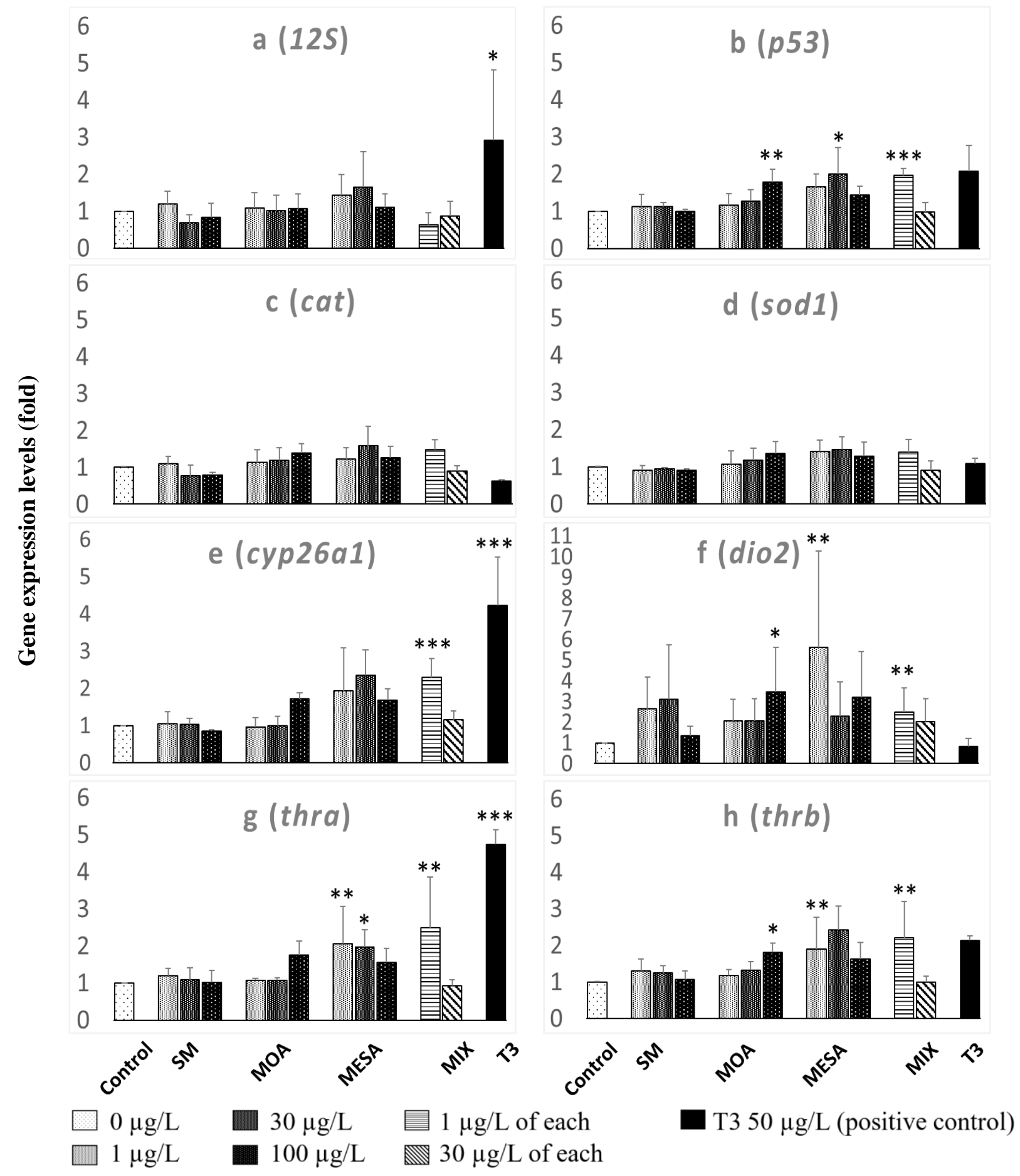

Figure 2. Expression levels of selected genes involved in mitochondrial metabolism (a), regulation of the cell cycle (b), oxidative stress defense (c, d), and thyroid metabolism disruption (e,f,g,h) associated genes in zebrafish larvae exposed for 5 days to SM: S-metolachlor; MOA: Metolachlor oxanilic acid; MESA: Metolachlor ethanesulfonic acid; MIX: mixture of SM, MOA and MESA; T3:

371 triiodothyronine hormone; $\mathrm{P}<0.05 ; * * \mathrm{P}<0.01 ; * * * \mathrm{P}<0.001$ 


\section{Discussion}

373 S-metolachlor and its metabolites are among the most commonly reported herbicides

374 occurring in relatively high concentrations in European waterbodies (Accinelli et al., 2002;

375 Cerejeira et al., 2003; Farlin et al., 2018; Kapsi et al., 2019; Meffe and de Bustamante, 2014;

376 Vryzas et al., 2009). Despite of the overall importance, the toxicity of S-metolachlor on fish 377 was commonly evaluated at environmentally non-relevant conditions and high concentrations

378 (Quintaneiro et al., 2017) or using only the racemic mixture of metolachlor (Jin et al., 2011). 379 More recently, toxicity of one of the metabolites - MOA, was assessed by Velisek et al. 380 (2018a) on crayfish but the effects of S-metolachlor and its metabolites on fish remain poorly 381 characterized. Our interest was mainly focused on thyroid disruption, due to findings of Jin et 382 al. (2011) and Yang et al. (2015) who linked this type of disruption with some 383 chloroacetanilide pesticides. Regarding the complexity of the thyroid system, an integrative 384 approach combining multiple endpoints was used.

\section{$385 \quad 4.1$ Effects on embryo-larval development}

386 Few statistically significant induced malformations were detected in the present study but 387 only at higher exposure levels. Spine deformations were induced in fish exposed to mixture of 388 substances $(30 \mu \mathrm{g} / \mathrm{L}$ of each of the three compounds, $\sim 90 \mu \mathrm{g} / \mathrm{L}$ sum concentration) but, 389 interestingly, no such effects were observed at any of the substances alone up to $300 \mu \mathrm{g} / \mathrm{L}$. 390 Apparently, concentration addition (CA) effects in the mixture of different compounds was a 391 major driver beyond this observation (European Chemicals Agency, 2014). Correspondingly, 392 Lydy et al., (2004) discuss that, generally, pesticides of the same chemical class exert the CA 393 effects. This is supported also by findings of Junghans et al. (2003) who reported the CA 394 effects of the mixture of eight chloroacetanilide herbicides in the study with susceptible 395 organism - algae. It should be noted that despite of the statistical significance, the frequency 396 of spine malformation (4.6\%) is rather low and might be of minor biological significance. 397 Nevertheless, further experiments could eventually further explore the mechanism behind this 398 observation.

399 Other significant malformations (craniofacial deformations, non-inflated swim bladder, yolk 400 sac malabsorption) were induced by individual substances at higher concentrations (100 or $401300 \mu \mathrm{g} / \mathrm{L})$. The observed malformations could be linked to the disruption of thyroid signaling. 402 Liu and Chan (2002) showed that thyroid disruption lead to retarded inflation of the swim 403 bladder, retarded absorption of the yolk sac and retarded maturation of the gastrointestinal 
system. Quintaneiro et al. (2017) described impairment of yolk sac absorption of $96 \mathrm{hpf}$

405 zebrafish larvae exposed to high concentrations of S-metolachlor (45 mg/L).

406 In our study, no statistically significant mortality was observed for tested concentrations of all 407 substances and the mixture. According to U.S. EPA Ecotox database the NOEL of $408 \mathrm{~S}$-metolachlor for bluegill is $1.5 \mathrm{mg} / \mathrm{L}$ and for rainbow trout $2.5 \mathrm{mg} / \mathrm{L}$ (measured at $96 \mathrm{hpf}$ ). 409 Both concentrations are higher than our highest tested concentration of $300 \mu \mathrm{g} / \mathrm{L}$. To our 410 knowledge, no data are available for the effects of metabolites on fish. Recently, Velisek et al. 411 (2018a) found no mortality of embryo-larval stages of crayfish exposed for 45 days up to $412420 \mu \mathrm{g} / \mathrm{L}$ of MOA. No effect was found on the length of larvae or the hatching success of fish 413 exposed to tested substances and the mixture. This finding is in concordance with 100 times 414 higher LOEC (29.0 mg/L) of S-metolachlor for zebrafish embryos (96 hpf) for hatching 415 success established by Quintaneiro et al. (2017). Thus, as it was expected, low 416 environmentally relevant concentrations used in this study elicited no significant effects on 417 traditional apical endpoints such as mortality, hatching success and length of zebrafish larvae 418 and we further investigated other sublethal endpoints.

\section{$419 \quad 4.3$ Effects on behavior}

420 Use of zebrafish larvae in behavioral studies have multiple advantages for evaluation of 421 neurotoxicity of pesticides as discussed by Pittman (2017). To our knowledge, this is the first study that investigated the effects of S-metolachlor and its metabolites on fish behavior although some studies suggested S-metolachlor effects on neurobehavior. Quintaneiro et al.

424 (2017) exposed zebrafish embryos for 4 days to $25 \mathrm{mg} / \mathrm{L}$ of S-metolachlor and observed 425 inhibited acetylcholinesterase activity. Villa et al. (2018) described decreased speed and 426 distance travelled by Chironomous larvae upon metolachlor exposures $(27.4 \mathrm{mg} / \mathrm{L})$. Cook \& 427 Moore (2008) found that sublethal concentration of metolachlor ( $80 \mu \mathrm{g} / \mathrm{L})$ altered the fighting 428 behavior of crayfish. On the contrary, available study with MOA revealed no effect on the 429 behavior of crayfish (activity, distance, speed) exposed up to $420 \mu \mathrm{g} / \mathrm{L}$ (Velisek et al., 430 2018a). Moreover, some pesticides of the same chemical class of chloroacetanilides were also 431 reported to influence fish locomotion. Pretilachlor $(1 \mathrm{mg} / \mathrm{L})$ decreased feeding attempts and 432 increased burst swimming reactions and buccal movements in adult fish Clarias batrachus 433 (Soni and Verma, 2018). Acetochlor at $5 \mathrm{mg} / \mathrm{L}$ decreased spontaneous tail movements in 434 zebrafish embryos ( $24 \mathrm{hpf})$ as well as total distance travelled, average speed and time of 435 movement of larvae 6 dpf (Wang et al., 2019). 
436 In the present study, S-metolachlor decreased spontaneous tail movements in zebrafish 437 embryos, although this observation was recorded only in the lowest concentration $(1 \mu \mathrm{g} / \mathrm{L})$. 438 Corresponding decrease was also observed after exposure to the lower concentration mixture 439 (all three compounds, $1 \mu \mathrm{g} / \mathrm{L}$ each). The observed effects on spontaneous movements may be caused by S-metolachlor interfering with maternal T4 stock in yolk sac or its signaling via an $\alpha \mathrm{V} \beta 3$ integrin as shown by Yonkers and Ribera (2008). The thyroid follicles start to secrete T4 hormone at 72 hpf (Porazzi et al., 2009), and nongenomic mechanism with maternal T4 443 influencing the neurodevelopment of zebrafish was previously reported (Yonkers and Ribera, 444 2008).

445 On the contrary, light:dark locomotion test didn't reveal any abnormal behavior. High 446 biological variability in larvae movement could be linked to relatively wide time frame within 447 the day (9 am $-4 \mathrm{pm})$, when the measurements were carried out. This was discussed by some 448 authors who recommend specific more narrow frames like 11 am -3 pm (Colwill and Creton, 449 2011) or 1 pm - 3:30 pm (MacPhail et al., 2009).

\subsection{Effects on gene expression}

451 Exposures to the metabolites appeared to have more pronounced effects on zebrafish larvae 452 than the exposure to the parent compound. The highest tested concentration $(100 \mu \mathrm{g} / \mathrm{L})$ of 453 MOA caused overexpression of genes dio2, thrb and p53. MESA induced overexpression of 454 dio2, thra and thrb in fish exposed to low $1 \mu \mathrm{g} / \mathrm{L}$, and thra and p53 in fish exposed to $30 \mu \mathrm{g} / \mathrm{L}$. The induction of p53 indicates an activation of apoptotic processes or cell cycle arrest to protect the cells from additional detrimental effects (Ko and Prives, 1996). Genes dio2, thra, thrb, were proposed by Jin et al., (2011) as suitable biomarkers for thyroid system disruption in fish. Spaan et al., (2019) describe them as important genes (together with other deiodinases diol and dio3 and genes hhex and NIS) in the HPT axis. Deiodinase 2 is a selenoprotein that catalyzes the transformation of $\mathrm{T} 4$ to $\mathrm{T} 3$, thyroid hormones regulating the neurodevelopment. It is the most important deiodinase in zebrafish embryonic development as it controls the quantity of T3 hormone in the tissues (Walpita et al., 2009). Furthermore, deiodinases were found to affect the eye development of zebrafish (Houbrechts et al., 2016) and the overexpression of dio2 has been linked with hypothyroidism (Orozco and Valverde-R, 2005). Thyroid hormone receptors $\alpha \mathrm{a}$ and $\beta$ act as transcription factors for thyroid hormones. According to Walter et al. (2019), mRNA levels of deiodinases and thyroid hormone receptors vary throughout the zebrafish development, with expression peak of dio2 and thrb around $72-96 \mathrm{hpf}$ and following decrease at $120 \mathrm{hpf}$. Expression of thra is stable from $24 \mathrm{hpf}$ 
to 120 hpf. Furthermore, as described by Porazzi et al., (2009) and Raldúa et al., (2012), thyroid system in zebrafish is fully developed during $5 \mathrm{dpf}$.

Although MESA and MOA affected expressions of several genes, no changes were observed after exposure to S-metolachlor. Contradictory observations for S-metolachlor were found by Jin et al. (2011), where $10 \mu \mathrm{g} / \mathrm{L}$ caused overexpression of dio2, thra and thrb in juvenile medaka, only in females. These differences may be related to multiple factors such as exposure duration (14 days in Jin et al. (2011) in comparison to 5 days in our study) or use of racemic mixture of metolachlor by Jin et al. (2011), which has been found more toxic to nontarget organisms than pure S-metolachlor (Liu et al., 2006; Ye et al., 2010). Use of different fish species in different life stage (1-month-old juveniles used by Jin et al. (2011) in comparison with embryos in the present study) is also of importance; differences in sensitivity of medaka and zebrafish have already been documented (Perrichon et al., 2014; Vignet et al., 2019).

The mixture of S-metolachlor and its two metabolites appeared to be most hazardous, and low environmental concentration ( $1 \mu \mathrm{g} / \mathrm{L}$ of each substance) altered transcription of several genes like p53, dio2, thra, thrb and cyp26al. Gene cyp26al, encoding for enzyme degrading retinoic acid, is very important in embryogenesis, and its overexpression can disturb all the retinoic acid signalling pathway and may lead to developmental malformations ( $\mathrm{Hu}$ et al., 2008). Effects on gene expression observed at low concentration of the mixture were not confirmed at the high concentration. This mixture "low-dose effects" mechanism has been discussed in the field of thyroid, and generally endocrine, system disruption, where nonmonotonic responses and U-shaped dose-response curves have been documented (Melnick et al., 2002; Vandenberg et al., 2012).

The most known pesticides to exert thyroid dysfunction are organochlorine pesticides (Calsolaro et al., 2017). However, several chloroacetanilides have also been shown to disrupt the thyroid system including the above discussed metolachlor in adult and juvenile medaka (Jin et al., 2011), acetochlor (Jiang et al., 2015; Yang et al., 2015) and pretilachlor (Jiang et al., 2016) in zebrafish embryos, acetochlor in larval rare minnow (Li et al., 2009) or butachlor in adult rare minnow (Zhu et al., 2014). Similarly to the present work, the above-mentioned studies documented changes in gene expressions of deiodinases and thyroid nuclear receptors and used lower concentrations below hundreds of micrograms. Comparatively, Li et al., (2009) and Yang et al., (2015) also mentioned a non-sigmoidal dose response curve. 
501 No changes were observed in the expression of the next three genes: $12 \mathrm{~S}$, sodl and cat. Gene $50212 S$ is associated with mitochondrial metabolism thus suggesting no effect on metabolic 503 homeostasis (Arini et al., 2015). Sodl and cat are important genes managing some parts of the 504 chain of the reactive oxygen species (ROS) in cell, scavenging respectively the superoxide 505 radicals and hydrogen peroxide (Seifried et al., 2007). From these findings we conclude that 506 S-metolachlor, its two metabolites and their mixture did not induce any oxidative stress 507 detectable by sodl and cat in the zebrafish embryos. Quintaneiro et al. (2017) did not found 508 either an effect of S-metolachlor on the catalase activity in zebrafish embryos exposed up to $50925 \mathrm{mg} / \mathrm{L}$. In contrast, MOA seems to have an inhibiting effect on catalase activity of a water 510 crustacean: crayfish exposed to low concentrations $(4.2 \mu \mathrm{g} / \mathrm{L})$ (Velisek et al., 2018a). 


\section{5. Conclusion}

513 Our work brings important findings about the effects of environmentally relevant mixture of 514 one of the most used herbicides S-metolachlor and its two metabolites on early life stages of 515 zebrafish. We have observed specific malformations that could be linked to thyroid disruption 516 as well as decreased spontaneous movements of zebrafish larvae. Interestingly, metabolites 517 were more harmful that S-metolachlor to zebrafish larvae at the level of gene expression with 518 apparently strong effects on genes involved in cell cycle regulation and thyroid-related 519 signaling. Further detailed analyses are needed to fully elucidate the dose-response 520 relationship. The present study brings new information highlighting the importance of 521 metabolites and the pesticides mixtures as emphasized in the European Environmental Action 522 Programme (European Parliament and Council, 2013). 


\section{References}

Accinelli, C., Vicari, A., Pisa, P.R., Catizone, P., 2002. Losses of atrazine, metolachlor, prosulfuron and triasulfuron in subsurface drain water. I. Field results. Agronomie 22, 399-411.

Alt, B., Reibe, S., Feitosa, N.M., Elsalini, O.A., Wendl, T., Rohr, K.B., 2006. Analysis of origin and growth of the thyroid gland in zebrafish. Dev. Dyn. 235, 1872-1883.

Arini, A., Gourves, P.Y., Gonzalez, P., Baudrimont, M., 2015. Metal detoxification and gene expression regulation after a $\mathrm{Cd}$ and $\mathrm{Zn}$ contamination: An experimental study on Danio rerio. Chemosphere 128, 125-133.

Atwood, D., Paisley-Jones, C., 2017. Pesticides Industry Sales and Usage 2008 - 2012.

Blaser, H.-U., Spindler, F., 1997. Enantioselective catalysis for agrochemicals. The case histories of (S)-metolachlor, (R)-metalaxyl and clozylacon. Top. Catal. 4, 275-282.

Calsolaro, V., Pasqualetti, G., Niccolai, F., Caraccio, N., Monzani, F., 2017. Thyroid Disrupting Chemicals. Int. J. Mol. Sci. 18.

Cerejeira, M.., Viana, P., Batista, S., Pereira, T., Silva, E., Valério, M.., Silva, A., Ferreira, M., SilvaFernandes, A.., 2003. Pesticides in Portuguese surface and ground waters. Water Res. 37, 10551063.

CHMU (Czech Hydrometeorological Institute), 2018. Online water quality database [Database]. URL www.hydro.chmi.cz/pasporty (accessed 11.28.18).

Colwill, R.M., Creton, R., 2011. Locomotor behaviors in zebrafish (Danio rerio) larvae. Behav. Processes 86, 222-229.

Cook, M.E., Moore, P.A., 2008. The Effects of the Herbicide Metolachlor on Agonistic Behavior in the Crayfish, Orconectes rusticus. Arch. Environ. Contam. Toxicol. 55, 94-102.

De Liguoro, M., Bona, M.D., Gallina, G., Capolongo, F., Gallocchio, F., Binato, G., Di Leva, V., 2014. A monitoring of chemical contaminants in waters used for field irrigation and livestock watering in the Veneto region (Italy), using bioassays as a screening tool. Environ. Sci. Pollut. Res. 21, 3546-3557.

Dedeh, A., Ciutat, A., Treguer-Delapierre, M., Bourdineaud, J.P., 2015. Impact of gold nanoparticles on zebrafish exposed to a spiked sediment. Nanotoxicology 9, 71-80.

Dobšíková, R., Blahová, J., Modrá, H., Škorič, M., Svobodová, Z., 2011. The effect of acute exposure to herbicide Gardoprim Plus Gold 500 SC on haematological and biochemical indicators and histopathological changes in common carp (Cyprinus carpio L.). ACTA VET 80, 359-363.

Elliott, S.M., VanderMeulen, D.D., 2017. A regional assessment of chemicals of concern in surface waters of four Midwestern United States national parks. Sci. Total Environ. 579, 1726-1735.

European Chemicals Agency, 2014. Transitional Guidance on the Biocidal Products Regulation: Transitional Guidance on mixture toxicity assessment for biocidal products for the environment.

European Parliament and Council, 2013. General Union Environment Action Programme to 2020 "Living well, within the limits of our planet."

Farlin, J., Gallé, T., Bayerle, M., Pittois, D., Köppchen, S., Krause, M., Hofmann, D., 2018. Breakthrough dynamics of s-metolachlor metabolites in drinking water wells: Transport pathways and time to trend reversal. J. Contam. Hydrol. 213, 62-72.

Fauvelle, V., Belles, A., Budzinski, H., Mazzella, N., Plus, M., 2018. Simulated conservative tracer as a proxy for S-metolachlor concentration predictions compared to POCIS measurements in 
Arcachon Bay. Mar. Pollut. Bull. 133, 423-427.

Gentès, S., Maury-Brachet, R., Feng, C., Pedrero, Z., Tessier, E., Legeay, A., Mesmer-Dudons, N., Baudrimont, M., Maurice, L., Amouroux, D., Gonzalez, P., 2015. Specific Effects of Dietary Methylmercury and Inorganic Mercury in Zebrafish (Danio rerio) Determined by Genetic, Histological, and Metallothionein Responses. Environ. Sci. Technol. 49, 14560-14569.

Glinski, D.A., Purucker, S.T., Van Meter, R.J., Black, M.C., Henderson, W.M., 2018. Analysis of pesticides in surface water, stemflow, and throughfall in an agricultural area in South Georgia, USA. Chemosphere 209, 496-507.

Götz, T., Böger, P., 2004. The Very-Long-Chain Fatty Acid Synthase Is Inhibited by Chloroacetamides. Verlag der Zeitschrift für Naturforsch. 549-553.

Gustavsson, M., Kreuger, J., Bundschuh, M., Backhaus, T., 2017. Pesticide mixtures in the Swedish streams: Environmental risks, contributions of individual compounds and consequences of single-substance oriented risk mitigation. Sci. Total Environ. 598, 973-983.

Gutiérrez, I.B., Mesquita, A.F., Gonçalves, F.J.M., Marques, J.C., Gonçalves, A.M.M., 2019. Biomarkers' responses of the benthic clam Scrobicularia plana to the main active ingredients (Smetolachlor and Terbuthylazine) of a common herbicide. Ecol. Indic. 96, 611-619.

Hayes, A.W., Li, R., Hoeng, J., Iskandar, A., Peistch, M.C., Dourson, M.L., 2019. New approaches to risk assessment of chemical mixtures. Toxicol. Res. Appl. 3, 1-10.

Heydens, W.F., Lamb, I.C., Wilson, A.G.E., 2010. Chloracetanilides. Hayes' Handb. Pestic. Toxicol. $1753-1769$.

Hladik, M.L., Hsiao, J.J., Roberts, A.L., 2005. Are Neutral Chloroacetamide Herbicide Degradates of Potential Environmental Concern? Analysis and Occurrence in the Upper Chesapeake Bay. Environ. Sci. Technol. 39, 6561-6574.

Houbrechts, A.M., Vergauwen, L., Bagci, E., Van houcke, J., Heijlen, M., Kulemeka, B., Hyde, D.R., Knapen, D., Darras, V.M., 2016. Deiodinase knockdown affects zebrafish eye development at the level of gene expression, morphology and function. Mol. Cell. Endocrinol. 424, 81-93.

Hu, P., Tian, M., Bao, J., Xing, G., Gu, X., Gao, X., Linney, E., Zhao, Q., 2008. Retinoid regulation of the zebrafish cyp26al promoter. Dev. Dyn. 237, 3798-3808.

ISO, 1996. ISO 7346-2:1996 - Water quality -- Determination of the acute lethal toxicity of substances to a freshwater fish [Brachydanio rerio Hamilton-Buchanan (Teleostei, Cyprinidae)] -- Part 1: Static method; Part 2: Semi-static method.

Jarque, S., Piña, B., 2014. Deiodinases and thyroid metabolism disruption in teleost fish. Environ. Res. $135,361-375$.

Jiang, J., Chen, Y., Yu, R., Zhao, X., Wang, Q., Cai, L., 2016. Pretilachlor has the potential to induce endocrine disruption, oxidative stress, apoptosis and immunotoxicity during zebrafish embryo development. Environ. Toxicol. Pharmacol. 42, 125-134.

Jiang, J., Wu, S., Liu, X., Wang, Y., An, X., Cai, L., Zhao, X., 2015. Effect of acetochlor on transcription of genes associated with oxidative stress, apoptosis, immunotoxicity and endocrine disruption in the early life stage of zebrafish. Environ. Toxicol. Pharmacol. 40, 516-523.

Jin, Y., Chen, R., Wang, L., Liu, J., Yang, Y., Zhou, C., Liu, W., Fu, Z., 2011. Effects of metolachlor on transcription of thyroid system-related genes in juvenile and adult Japanese medaka (Oryzias latipes). Gen. Comp. Endocrinol. 170, 487-493.

Junghans, M., Backhaus, T., Faust, M., Scholze, M., Grimme, L.H., 2003. Predictability of combined effects of eight chloroacetanilide herbicides on algal reproduction. Pest Manag. Sci. 59, 11011110 . 
Kapsi, M., Tsoutsi, C., Paschalidou, A., Albanis, T., 2019. Environmental monitoring and risk assessment of pesticide residues in surface waters of the Louros River (N.W. Greece). Sci. Total Environ. 650, 2188-2198.

Ko, L.J., Prives, C., 1996. p53: Puzzle and paradigm. Genes Dev. 10, 1054-1072.

Lerebours, A., Gonzalez, P., Adam, C., Camilleri, V., Bourdineaud, J.-P., Garnier-Laplace, J., 2009. Comparative analysis of gene expression in brain, liver, skeletal muscles, and gills of zebrafish (Danio rerio) exposed to environmentally relevant waterborne uranium concentrations. Environ. Toxicol. Chem. 28, 1271-1278.

Li, W., Zha, J., Li, Z., Yang, L., Wang, Z., 2009. Effects of exposure to acetochlor on the expression of thyroid hormone related genes in larval and adult rare minnow (Gobiocypris rarus). Aquat. Toxicol. 94, 87-93.

Liu, H., Ye, W., Zhan, X., Liu, W., 2006. A comparative study of rac- and S-metolachlor toxicity to Daphnia magna. Ecotoxicol. Environ. Saf. 63, 451-455.

Liu, Y.-W., Chan, W.-K., 2002. Thyroid hormones are important for embryonic to larval transitory phase in zebrafish. Differentiation 70, 36-45.

Livak, K.J., Schmittgen, T.D., 2001. Analysis of relative gene expression data using real-time quantitative PCR and the 2(-Delta Delta C(T)) Method. Methods 25, 402-8.

Love, D.R., Pichler, F.B., Dodd, A., Copp, B.R., Greenwood, D.R., 2004. Technology for highthroughput screens: the present and future using zebrafish. Curr. Opin. Biotechnol. 15, 564-571.

Lydy, M., Belden, J., Wheelock, C., Hammock, B., Denton, D., 2004. Challenges in Regulating Pesticide Mixtures. Ecol. Soc. 9.

MacPhail, R.C., Brooks, J., Hunter, D.L., Padnos, B., Irons, T.D., Padilla, S., 2009. Locomotion in larval zebrafish: Influence of time of day, lighting and ethanol. Neurotoxicology 30, 52-58.

Mai, H., Gonzalez, P., Pardon, P., Tapie, N., Budzinski, H., Cachot, J., Morin, B., 2014. Comparative responses of sperm cells and embryos of Pacific oyster (Crassostrea gigas) to exposure to metolachlor and its degradation products. Aquat. Toxicol. 147, 48-56.

Meffe, R., de Bustamante, I., 2014. Emerging organic contaminants in surface water and groundwater: A first overview of the situation in Italy. Sci. Total Environ. 481, 280-295.

Melnick, R., Lucier, G., Wolfe, M., Hall, R., Stancel, G., Prins, G., Gallo, M., Reuhl, K., Ho, S.-M., Brown, T., Moore, J., Leakey, J., Haseman, J., Kohn, M., 2002. Summary of the National Toxicology Program's report of the endocrine disruptors low-dose peer review. Environ. Health Perspect. 110, 427-31.

Müller, M.D., Poiger, T., Buser, H.-R., 2001. Isolation and Identification of the Metolachlor Stereoisomers Using High-Performance Liquid Chromatography, Polarimetric Measurements, and Enantioselective Gas Chromatography. J. Agric. Food Chem. 49, 42-49.

Munn, M.D., Gilliom, R.J., Moran, P.W., Nowell, L.H., 2006. Pesticide Toxicity Index for Freshwater Aquatic Organisms, 2nd Edition.

OECD, 2013. Test No. 210: Fish early life stage toxicity test. OECD Guideline for the testing of chemicals. [WWW Document]. URL https://www.oecd-ilibrary.org/docserver/9789264203785en.pdf?expires $=1568722812 \& i d=i d \& a c c n a m e=0 c i d 56014292 \&$ checksum $=$ A5DDCACDA2BC 8 F0AAD663E4B7777B894 (accessed 9.9.16).

Oliveira, E., Casado, M., Raldúa, D., Soares, A., Barata, C., Na, B.P., 2013. Retinoic acid receptors' expression and function during zebrafish early development. J. Steroid Biochem. Mol. Biol. 138, $143-151$. 
Orozco, A., Valverde-R, C., 2005. Thyroid Hormone Deiodination in Fish. Thyroid 15, 799-813.

657 Panzica-Kelly, J.M., Zhang, C.X., Danberry, T.L., Flood, A., DeLan, J.W., Brannen, K.C., AugustineRauch, K.A., 2010. Morphological score assignment guidelines for the dechorionated zebrafish teratogenicity assay. Birth Defects Res. Part B - Dev. Reprod. Toxicol. 89, 382-395.

660

661

662

663

664

665

666

667

668

669

670

671

672

673

674

675

676

677

678

679

680

681

682

683

684

685

686

687

688

689

690

691

692

693

694

695

696

697

698

699

Perrichon, P., Le Bihanic, F., Bustamante, P., Le Menach, K., Budzinski, H., Cachot, J., Cousin, X., 2014. Influence of sediment composition on PAH toxicity using zebrafish (Danio rerio) and Japanese medaka (Oryzias latipes) embryo-larval assays. Environ. Sci. Pollut. Res. 21, 1370313719.

Pittman, J., 2017. Zebrafish Neurotoxicity Models, in: Kalueff, A.V. (Ed.), The Rights and Wrongs of Zebrafish: Behavioral Phenotyping of Zebrafish. Springer, pp. 207-219.

Porazzi, P., Calebiro, D., Benato, F., Tiso, N., Persani, L., 2009. Thyroid gland development and function in the zebrafish model. Mol. Cell. Endocrinol. 312, 14-23.

Quintaneiro, C., Patrício, D., Novais, S.C., Soares, A.M.V.M., Monteiro, M.S., 2017. Endocrine and physiological effects of linuron and S-metolachlor in zebrafish developing embryos. Sci. Total Environ. 586, 390-400.

Quintaneiro, C., Soares, A.M.V.M., Monteiro, M.S., 2018. Effects of the herbicides linuron and Smetolachlor on Perez's frog embryos. Chemosphere 194, 595-601.

Raldúa, D., Thienpont, B., Babin, P.J., 2012. Zebrafish eleutheroembryos as an alternative system for screening chemicals disrupting the mammalian thyroid gland morphogenesis and function. Reprod. Toxicol. 33, 188-197.

Rose, M.T., Cavagnaro, T.R., Scanlan, C.A., Rose, T.J., Vancov, T., Kimber, S., Kennedy, I.R., Kookana, R.S., Van Zwieten, L., 2016. Impact of Herbicides on Soil Biology and Function. Adv. Agron. 136, 133-220.

Russell, W.M.S., Burch, R.L., Hume, C.W., 1959. The Principles of Humane Experimental Technique. Methuen, London.

Ryberg, K.R., Vecchia, A. V, Gilliom, R.J., Martin, J.D., 2014. Pesticide Trends in Major Rivers of the United States, 1992-2010.

Seifried, H.E., Anderson, D.E., Fisher, E.I., Milner, J.A., 2007. A review of the interaction among dietary antioxidants and reactive oxygen species. J. Nutr. Biochem. 18, 567-579.

Sidoli, P., Lassabatere, L., Angulo-Jaramillo, R., Baran, N., 2016. Experimental and modeling of the unsaturated transports of S-metolachlor and its metabolites in glaciofluvial vadose zone solids. J. Contam. Hydrol. 190, 1-14.

Soni, R., Verma, S.K., 2018. Acute toxicity and behavioural responses in Clarias batrachus (Linnaeus) exposed to herbicide pretilachlor. Heliyon 4, e01090.

Spaan, K., Haigis, A.-C., Weiss, J., Legradi, J., 2019. Effects of 25 thyroid hormone disruptors on zebrafish embryos: A literature review of potential biomarkers. Sci. Total Environ. 656, 1238 1249.

Thomas Poiger, M.D.M.\& H.-R.B., 2002. Verifying the Chiral Switch of the Pesticide Metolachlor on the Basis of the Enantiomer Composition of Environmental Residues 56, 300-303.

Tian, D., Mao, H., Lv, H., Zheng, Y., Peng, C., Hou, S., 2018. Novel two-tiered approach of ecological risk assessment for pesticide mixtures based on joint effects. Chemosphere 192, 362371.

U.S. Environmental Protection Agency, 1992. ECOREF \#334 [Database]. Pestic. Ecotoxicity Database. URL https://cfpub.epa.gov/ecotox/search.cfm (accessed 1.8.19). 
Vandenberg, L.N., Colborn, T., Hayes, T.B., Heindel, J.J., Jacobs, D.R., Lee, D.-H., Shioda, T., Soto, A.M., vom Saal, F.S., Welshons, W. V, Zoeller, R.T., Myers, J.P., Myers, J.P., 2012. Hormones and endocrine-disrupting chemicals: low-dose effects and nonmonotonic dose responses. Endocr. Rev. 33, 378-455.

Velisek, J., Stara, A., Zuskova, E., Kubec, J., Buric, M., Kouba, A., 2018a. Chronic toxicity of metolachlor OA on growth, ontogenetic development, antioxidant biomarkers and histopathology of early life stages of marbled crayfish. Sci. Total Environ. 643, 1456-1463.

Velisek, J., Stara, A., Zuskova, E., Kubec, J., Buric, M., Kouba, A., 2018b. Effects of s-metolachlor on early life stages of marbled crayfish. Pestic. Biochem. Physiol.

Vignet, C., Cappello, T., Fu, Q., Lajoie, K., De Marco, G., Clérandeau, C., Mottaz, H., Maisano, M., Hollender, J., Schirmer, K., Cachot, J., 2019. Imidacloprid induces adverse effects on fish early life stages that are more severe in Japanese medaka (Oryzias latipes) than in zebrafish (Danio rerio). Chemosphere.

Villa, S., Di Nica, V., Pescatore, T., Bellamoli, F., Miari, F., Finizio, A., Lencioni, V., 2018. Comparison of the behavioural effects of pharmaceuticals and pesticides on Diamesa zernyi larvae (Chironomidae). Environ. Pollut. 238, 130-139.

Vryzas, Z., Vassiliou, G., Alexoudis, C., Papadopoulou-Mourkidou, E., 2009. Spatial and temporal distribution of pesticide residues in surface waters in northeastern Greece. Water Res. 43, 1-10.

Walpita, C.N., Crawford, A.D., Janssens, E.D.R., Van der Geyten, S., Darras, V.M., 2009. Type 2 Iodothyronine Deiodinase Is Essential for Thyroid Hormone-Dependent Embryonic Development and Pigmentation in Zebrafish. Endocrinology 150, 530-539.

Walter, K.M., Miller, G.W., Chen, X., Yaghoobi, B., Puschner, B., Lein, P.J., 2019. Effects of thyroid hormone disruption on the ontogenetic expression of thyroid hormone signaling genes in developing zebrafish (Danio rerio). Gen. Comp. Endocrinol. 272, 20-32.

Wang, H., Meng, Z., Zhou, L., Cao, Z., Liao, X., Ye, R., Lu, H., 2019. Effects of acetochlor on neurogenesis and behaviour in zebrafish at early developmental stages. Chemosphere 220, 954 964.

Yan, W., Zhou, Y., Yang, J., Li, S., Hu, D., Wang, J., Chen, J., Li, G., 2012. Waterborne exposure to microcystin-LR alters thyroid hormone levels and gene transcription in the hypothalamicpituitary-thyroid axis in zebrafish larvae. Chemosphere 87, 1301-1307.

Yang, M., Hu, J., Li, S., Ma, Y., Gui, W., Zhu, G., 2015. Thyroid endocrine disruption of acetochlor on zebrafish (Danio rerio) larvae. J. Appl. Toxicol. n/a-n/a.

Ye, J., Zhao, M., Liu, J., Liu, W., 2010. Enantioselectivity in environmental risk assessment of modern chiral pesticides. Environ. Pollut. 158, 2371-2383.

Yonkers, M.A., Ribera, A.B., 2008. Sensory Neuron Sodium Current Requires Nongenomic Actions of Thyroid Hormone During Development. J Neu-rophysiol 100, 2719-2725.

Zemolin, C.R., Avila, L.A., Cassol, G.V., Massey, J.H., Camargo, E.R., 2014. Environmental fate of S-Metolachlor - A Review. Planta Daninha 32, 655-664.

Zhu, L., Li, W., Zha, J., Wang, M., Yuan, L., Wang, Z., 2014. Butachlor causes disruption of HPG and HPT axes in adult female rare minnow (Gobiocypris rarus). Chem. Biol. Interact. 221, 119-126. 